\title{
Financial Risk Management and the Profitability of Selected Deposit Money Banks in Nigeria
}

\author{
Akindutire, Solomon Olumayokun \\ Department of Accountancy, Federal Polytechnic, Ile-Oluji, Ondo, State Nigeria \\ Ibo, Sunday Adekoya \\ Department of Accountancy, Federal Polytechnic, Ile Oluji, Ondo State, Nigeria
}

\begin{abstract}
This study examined the effect of financial risks on profitability of selected Deposit Money Banks in Nigeria. The study employed secondary method of data collection. Data collected from the annual financial reports of the sampled Deposit Money banks over the period of 2008 to 2017 were analyzed using both descriptive and inferential statistics. Descriptive analyses conducted in the study include mean analysis while inferential analyses conducted in the study include correlation analysis, random effect regression and fixed effect panel data regression. The results revealed that credit risk has positive but insignificant relationship effect on ROA, ROE and EPS. Liquidity risk has positive but insignificant relationship effect on ROA and ROE but negative and insignificant relations with EPS. Interest rate has positive and significant relationship on ROE, while it has positive and insignificant effect on ROA and EPS. The study recommends that management of Deposit Money Banks in Nigeria should focus on credit risk management and keeping optimal level of liquidity to enables banks meet their contractual commitments and maximize return on assets of Deposit Money Banks in Nigeria.
\end{abstract}

Keywords: Financial risks, Profitability, Deposit Money Banks,

DOI: $10.7176 / \mathrm{EJBM} / 12-18-13$

Publication date:June 30th 2020

\section{Introduction}

Banks as financial intermediaries are very significant in the economy of every nation. Globally, banking activities are routinely performed through provision of loans and other facilities to their customers. Fundamentally, the existence of Deposit Money Banks is based on how well they manage the financial risks facing their operations. Deposit Money Banks, therefore, aim at achieving an acceptable equilibrium between risk and return whilst minimizing possible unacceptable outcomes on their performance. The implication here is that risk management is an integral part of Deposit Money Banks business activities as they are exposed to different risks in pursuit of their objectives. (Gande, 2008).

Holton (2004) viewed financial risk as the unexpected variability or volatility of returns. It is made up of credit risks, liquidity risks and market risks. Other components of financial risks include interest rate risk and currency risk. The bank's primary exposure to credit risk arises through its lending activity. Credit risk is the possibility that a debtor or borrower will not meet his repayment commitments to a lender (Greuning \& Bratanovic, 2009). Liquidity management is a daily activity in the banking business and is accomplished through administration of a bank's assets. Deposit Money Banks should be capable of establishing their optimal cash management requirement levels within the short term and long term and under various stress scenarios.

Interest rate risk is the uncertainty on interest rates as a result of unpredictable movements in interest rates which may expose the bank to unfavourable interest rates. Movements in interest rates influences financial performance of Deposit Money Banks by changing the expected net interest income and expenses. Deposit Money Banks incurred interest rate risk principally in the form of exposure to adverse changes in the market interest rates to the extent that interest-earning assets and interest-earning liabilities mature or re-price at different times or in differing amounts. Asset-liability risk management is developed taking into account the sensitivity of the bank to interest rate changes. (Drigă, 2007).

The objective of every banking institution is to operate profitably in order to maintain its stability and improve its growth and expansion.A healthy and sustainable profitability is therefore, very important in maintaining the stability of the banking system and for sustainable economic growth in general. In spite of this and the fact that banks are in the business of taking risk, it should be recognized that an institution need not engage in business in a manner that unnecessarily imposes risk upon it. Thus examining the effect which the financial risks have on the profitability of the Deposit Money Banks in Nigeria is essential as it will enable them to manage those risks effectively. To effectively analyze the financial performance of banks, there are various indicators which are adopted. The widely used measures of financial performance include the Return on Assets (ROA), which measures return per each invested unit, and Return on Equity (ROE), which measures accounting earnings for a period per unit of shareholder's equity. Return on equity is the widespread measure of financial performance and suggests a straight valuation of the financial return of a shareholder's investment in a company. This research in addition to 
the most generally used indicators of financial performance incorporates earning per share. This is very important in order to determine the effect of financial risk on the earning per share of the selected Deposit Money Banks in Nigeria.

\section{Statement of the Problem}

The Nigerian banking industry before the 2004 reform was a case of a system heading to a total collapse as incidence of failure and liquidation arising from weak capitalization and operational inefficiency were common phenomenon. Soludo (2004) opined that the problems facing most of Nigerian banks include persistent illiquidity, poor asset quality and unprofitable operations.

After the introduction of banking reform in year 2005, the banking industry in Nigeria experienced considerable changes such as high increase in their share capitals, introduction of modern technology and various business products. These gave birth to competition among the Deposit Money Banks in Nigeria. The competition leads the banks to extend huge amounts of credit with the main objective of increasing profitability which may result in non-performing loans and advances. For instance, NDIC (2016) reported that the total loans and advances to Nigerian economy stood at 13.33 Trillion Naira in 2015, an increase of 5.56 percent over the 12.63 Trillion Naira reported in 2014. The unaudited profit-before-tax (PBT) of the banking industry stood at N588.86 billion as at 31 st December, 2015, representing a decrease of 20.02 percent over N601.2 billion reported as at 31 st December, 2014 (NDIC, 2016).

The relevance of banks to the economy lies primarily in their ability to mobilize deposits and grant credits to various economic actors. Without a doubt, in the present erratic and volatile atmosphere, banks are faced with heavy risks like credit risk, liquidity risk, operational risk, market risk, and interest rate risk, along with other risks, which may possibly intimidate the survival and success of the Deposit MoneyBanks in Nigeria. (Rose, 2008). The implication that it is possible for Deposit Money Banks in Nigeria to face various challenges that include nonperforming loans and fluctuations of interest rate among others, which are threatening the bank stability. According to Bessis (2005), banks are 'risk machines' as they take risks, transform them and embed them in banking products and services. It is therefore an open secret that risks are uncertainties resulting in adverse variations of profitability which shows the financial performance or losses that show the bank's failure.

Theoretically, the trade-off between risk and return is well acknowledged - higher return comes with higher risk (Tafri, Hamid, Merer \& Omar, 2009). Empirical study conducted by Lartey and Boadi (2013) on the relationship between liquidity and the profitability of banks listed on the Ghanaian Stock Exchange revealed that for the period 2005 to 2010, both liquidity and profitability had a downward trend. The study concluded that there was a positive significant relationship between liquidity and profitability of the listed banks. Eneyew (2013) conducted a research on financial risks and profitability of commercial banks in Ethiopia. The study found that liquidity risk, inflation and interest risk were also the major factor that adversely affects profitability of Ethiopian commercial banks. Oluwasanmi, Uwuigbe and Uwuigbe (2015) investigated the impact of effective risk management on bank's financial performance in Nigeria. The study observed that there exists a negative nonsignificant relationship between risk management and bank's performance. None of these studies examined relationship between financial risks using credit risk, liquidity risk and interest rate risk as combined proxies for financial risks and as explanatory variables in determining the effect of financial risks on profitability of Deposit Money Banks in Nigeria. There are other components of financial risks like foreign exchange risk and market risk that were not captured in this study. The study is restricted to these three variables (credit risk, liquidity risk and interest rate risks) as components of financial risks. Dependent variables are Return on Asset (ROA), Return on Equity (ROE) and Earning per share (EPS) as proxies for profitability. None of the previous studies explored this dimension. These are the gaps created in other studies that this study filled.

\section{Objectives of the Study}

The broad objective of this study is to examine the effect of financial risks on profitability of Deposit Money Banks in Nigeria. The specific objectives are to:

i. examine the effect of credit risk, liquidity risk and interest rate risk on returns on asset (ROA) of Deposit Money Banks in Nigeria;

ii. evaluate the effect of credit risk, liquidity risk and interest rate risk on returns on equity (ROE) of Deposit Money Banks in Nigeria;

iii. assess the effect of credit risk, liquidity risk and interest rate risk on earning per share (EPS) of Deposit Money Banks in Nigeria.

\section{Research Questions}

The study addressed the following questions:

i. What is the effect of credit risk, liquidity risk and interest rate risk on Returns on Asset (ROA) of Deposit Money Banks in Nigeria? 
ii. What is the effect of credit risk, liquidity risk and interest rate risk on Returns on Equity (ROE) of Deposit Money Banks in Nigeria?

iii. How does credit risk, liquidity risk and interest rate risk affect Earning per Share (EPS) of Deposit Money Banks in Nigeria?

\section{Research Hypotheses}

The following null hypotheses were formulated and tested in the study to establish the relationship between financial risks and profitability of Deposit Money Banks in Nigeria:

$\mathrm{H}_{\mathrm{O} 1}$ : There are no significant effects of credit risk, liquidity risk and interest rate risk on returns on asset (ROA) of Deposit Money Banks in Nigeria.

$\mathrm{H}_{\mathrm{O} 2}$ : There are no significant effects of credit risk, liquidity risk and interest rate risk on returns on equity (ROE) of Deposit Money Banks in Nigeria.

$\mathrm{H}_{\mathrm{O} 3}$ : There are no significant effects of credit risk, liquidity risk and interest rate risk on earning per share (EPS) of Deposit Money Banks in Nigeria.

\section{Significance of the Study}

This study of effect of financial risks on profitability of Deposit Money Banks in Nigeria will contribute significantly to the field of knowledge by assisting the Chief Executive Officer of banks, top management and supervisors of Deposit Money Banks in Nigeria to evaluate the banks risk mechanisms in order to reduce losses, increase profitability and provide more liquidity than before so as to prevent banks' distress in Nigeria. The study contributed to existing local literatures on the subject matter. Furthermore, the study will help business analysts, financial and human resources consultants, other financial institutions, bankers and professionals alike to improve in their analytical, consulting and operational strategies to boost their client's performance, minimize risk in order to avoid the rippling effects that go with it.

This study will provide help to the policy makers especially government when formulating policies on the Banking sector and also in advising government in an efficient and effective way by which policy formulated can be implemented and consolidated in Nigeria. It will serve as a basis for developing appropriate policy and decision making particularly for economic growth and development. Stakeholders will also find this study very relevant and important because it will assist them in their deliberations on the effects and consequences of financial risk on Deposit Money Banks in Nigeria.

\section{Scope of the Study}

The focus of this study is on the effect of Financial Risks on Profitability of Deposit Money Banks in Nigeria. The study cut across ten listed Deposit Money Banks operating in Nigeria. The Deposit Money Banks are; First Bank of Nigeria, Guarantee Trust Bank, United Bank for Africa, Union Bank of Nigeria, Wema Bank, Access Bank, Fidelity Bank, Zenith Bank, Diamond Bank and Sterling Bank. The study covers ten years from 2008 to 2017.

\section{Literature Review}

Conceptual Review

Financial risks in Deposit Money Banks are risks that are associated with the provision of banking services, such as credit risk, liquidity risk, and interest risk. (Audit Office, 2000), defined risk as something happening that may have an impact on the achievement of objectives, and it include risk as an opportunity as well as a threat. The banking sector is considered to be an important source of financing for most businesses. Deposit Money banks are profit-making organizations acting as intermediaries between borrowers and lenders by attracting temporarily available resources from business and individual customers as well as granting loans for those in need of financial support. From this point of view, banks deal with money belonging to persons and other firms assuming a number of risks in the process of performing their responsibilities. Thus, risk is the possibility that a loss will occur and for any businesses it is a part of every decision. In fact, the essence of business decision making is comparing the gains and potential risks that are involved (Elsinger, Lehar \& Summer, 2003).

The nature of banking business contains an environment of high risk. So risky in the sense that it is the only business where proportion of borrowed funds is far higher than the owners' equity (Owojori, Akintoye \& Adidu, 2011). Crouhy, Galai and Mark, Crouhy, and Galai (2006) classified bank risk to include market risk, credit risk, liquidity risk, operational risk, legal risk, business risk, strategic risk, and reputation risk.

\section{Credit Risk}

Duffie and Singleton (2003), defined credit risk as the risk of default or of reductions in market value caused by changes in the credit quality of issuers or counterparties. Generally speaking, it is common in every business. Risk exists whenever a payment or performance to a contractual agreement by counterparty is expected. Conventionally, credit risk arises through lending, investment as well as credit advancement activities that 
concerns with the return of borrowed money or the payment for sold goods. Undoubtedly, when the obligation is not discharged completely, a loss occurs.

Experiences elsewhere in the world suggest that, credit risk is the major risk of a bank risks. Indeed, failure to collect loans granted to customers has been the major factor behind the collapse of many banks around the world. Credit risk is not confined to a bank's loan portfolio, but can also exist in its other assets and activities Similarly, such risk can exist in both a bank's on-balance sheet and its off-balance sheet accounts (NBE, 2010).

\section{Liquidity risk}

Liquidity risk is the potential for loss to an institution, arising from either its inability to meet its obligations or to fund increases in assets as they fall due. This risk is one of the risks a bank faces. According to the definition of the Basel Committee on Banking Supervision (2007), liquidity risk arises from the inability of a bank to accommodate decreases in liabilities or to fund increases in assets. When a bank has inadequate liquidity, it cannot obtain sufficient funds, either by increasing liabilities or by converting assets promptly, at a reasonable cost, thereby affecting profitability. Liquidity signifies the aptitude of a financial firm to always keep up all the time a balance between the financial inflow and outflow over time (Vento \& Ganga, 2009).

\section{Interest rate risk}

Interest rate risk arises from movements in interest rates. A bank is exposed to interest rate risk when it experiences a situation of imbalance in terms of size or maturity dates between assets and liabilities sensitive to interest rates, leading to potential losses for the bank when interest rate increases or declines and this influences the net asset value in the budget, which some call risk gap (Claudiu \& Daniela, 2009). Interest rate risk is the chance that an unexpected change in interest rates may affect the value of an investment negatively.

Fluctuations in interest rates may affect banks in different ways but almost every company is affected by changes in interest rates. A company that borrows or invests surplus funds does so at either a fixed rate of interest or at a floating (variable) rate. Fixed rates provide certainty as interest payments or receipts are known regardless of future interest-rate movements. However, there are also risks associated with fixed-rate debts. For long-term debts the company risks being locked in to a high interest rate if interest rates fall during the life of the loan. A floating-rate borrowing (or investment) varies through the life of the loan (or investment). Floating rates are usually expressed as a margin over an agreed reference rate and are reset at regular intervals (Collier, 2009).

\section{Banks Profitability and its Measurement}

Deposit money banks make profit by earning more money than what they pay for expenses and taxes. The most important position of a bank's profit comes from the fees that it charges for its services and the interest that it earns on its assets. Their major expenses are the interest paid on their liabilities. Loans dominate asset holding at most banks and generate the largest share of operating income. Loans are the most dominant asset in banks' portfolios, comprising from 50 to 70 percent of total assets (Claudiu \& Daniela, 2009).

The major assets of a bank are its loans to individuals, businesses and other organisations and the securities that it holds, while its major liabilities are its deposits and the money that it borrows, either from their banks or selling commercial paper in the money market. Return on asset (ROA) and return on equity (ROE) are the commonly used ratios to measure profitability of a business. Assets are used by businesses to generate income. Loans and securities are assets of banks and are used to generate most income to the bank. However, to be able to make loans available to their customers and buy securities, a bank must have money, which comes primarily from the bank's owners in the form of bank capital, from depositors, and from money that it borrows from other banks or by selling debt securities. A bank buys assets primarily with funds obtained from its liabilities. However, not all assets can be used to earn income, because banks must have cash to satisfy cash withdrawal requests of customers.

\section{The Relationship between Financial risks and Profitability}

Theoretically, it is expected that return on an asset should be positively related to its risk. That is, individuals will hold a risky asset only if its expected return compensates for its risk. Both the capital asset pricing model (CAPM) developed in the early 1960s and Arbitrage pricing theory (APT) imply a positive relationship between expected return and risk. Even, the APT views risk more generally than just the standardized covariance or beta of a security with the market portfolio. Therefore, risk-taking is an inherent element of banking and indeed profits are part of the reward for successful risk taking. In contrary, excessive, poorly managed risk can lead to distresses and failures of banks. The prime reason to adopt risk management practices is to avoid the probable failure in future. In fact, it is expensive in both resources and in institutional disruption. But the cost of delaying or avoiding proper risk management can lead to some adverse results, like failure of a bank and possibly failure of a banking system (Meyer, 2000). 
Theoretical Review

Liabilities Management Theory

The theory advocates that a bank can meet its liquidity requirement by bidding the marketfor additional funds. In other words, they can borrow money from the money market to meet their liquidity needs instead of granting selfliquidating loans (Jhingan, 2010).

\section{Liquidity AssetTheory}

The theory focuses on the asset side of the financial statements and argues that banks must hold large amount of liquid assets against possible demand or payments cushion of readilymarketable short term liquid assets against unforeseen circumstances (Ngwu, 2006).

\section{Shiftability Theory}

The theory is based on the proposition that banks liquidity is maintained if it holds assets that could be shifted or sold to other lenders or investors for cash. Also, these assets could be shifted to the Central Bank for cash without material loss in case of necessity than relying on maturities to solve their liquidity problems (Ngwu, 2006). This point of view contends that a bank's liquidity could be enhanced if it always has assets to sell and provided the Central Bank and Discount Market stands ready to purchase the asset offered for discount.

\section{Anticipated Income Theory}

This theory is of the view that banks liquidity can be estimated and met if scheduled payments are based on the income of the borrower. It emphasizes that banks should relate loans repayment to income rather than relying heavily on collaterals. That is, bank liquidity can be influenced by the maturity pattern of loans through customers' instalments rather than those secured by real estate (Ngwu, 2006).

\section{Finance Distress Theory}

Baldwin and Scott (1983) purported that when a firm's business deteriorates to the point where it cannot meet its financial obligation, the firm is said to have entered the state of financial distress. The first signals of financial distress are violations of debt payments and failure or reduction of dividends pay-outs. Whitaker (1999) defines entry in financial distress as the first year in which cash flows are less than current maturities' long-term debt. The firm has enough to pay its creditors as long as the cash flows exceeds the current debt obligations. The theory further stipulates that the key factor in identifying firms in financial distress are their inability to meet contractual debt obligations.

\section{Commercial Loan Theory}

This theory is also called the real bills theory. The theory states that banks should advance short term selfliquidating productive loans to business firms. In other words, banks should finance the movement of goods through the successive process of production so that once these goods are sold, the loans will liquidate themselves. Such loans are termed inventory or working capital loan (Ngwu, 2006)

\section{Theoretical frame work}

Commercial loan theory is the management oldest asset theory affecting and emerging when

European countries experience commerce tide in supporting the mercantilism. This theory, gives focus at role of asset side in fulfilling liquidity. Bank shall only give short-term credit likecirculating capital. The credit insurance, guaranteed by payment from the givers or debtor salesrevenue. Bank cannot give loan for debtor like securities purchasing, development of building, purchasing of investment goods, and other long-term borrowing. Thereby bases on this theory, bank can look after image from public sensitivity negativity opportunity.

Figure 1: A Schematic Diagram of Financial Risk and Profitability of DMB

\section{Risk Asset}

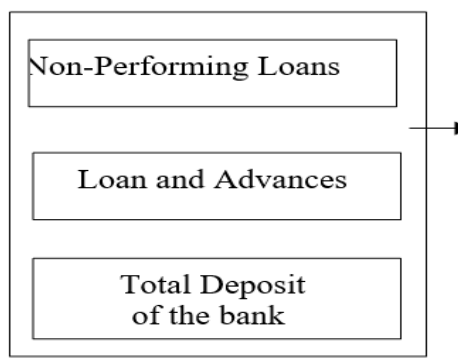

Source: Developed by the Researcher, 2018

\section{Financial Risk Bank Operating Performance}

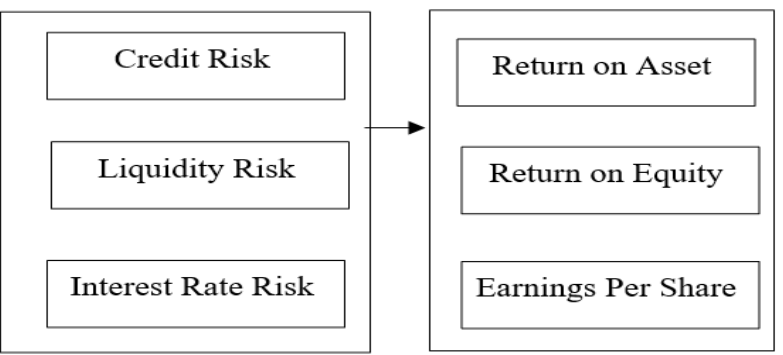




\section{Empirical Review}

\section{Review of Empirical Studies in Developed Countries}

Akhtar, Ali, and Sadaqat (2011) studied factors influencing the profitability of conventional Banks in Pakistan. They reported non-performing loans ratio is found to have negative and significant effect on the profitability of commercial banks.

The effect of liquid asset holdings on the profitability of U.S. and Canadian banks was investigated by Bordeleau, and Grahan (2010). The empirical results from ordinary least squares regression analysis of panel data of the banks suggested that profitability is improved for banks that hold some liquid assets. However, there is a point at which holding-further liquid assets minimizes a bank's profitability, all else equal. Furthermore, the empirical results from the study also indicated that this relationship varies depending on a bank's business model and the state of the economy.

\section{Review of Empirical Literature in Developing Countries}

Afriyie (2011) examined the impact of credit risk on the profitability of rural and community banks in the Brong Ahafo Region of Ghana. The study used the financial statements of ten rural banks from the period of 2006 to 2010 (five years) for analysis. The panel regression model was employed for the estimation. In the model, of Return on Equity (ROE) and Return on Asset (ROA) were used as profitability indicator while Non-Performing Loans Ratio (NLPR) and Capital Adequacy Ratio (CAR) as credit risk management indicators. The findings indicated a significant positive relationship between non-performing loans and rural banks' profitability revealing that, there are higher loan losses but banks still earn profit. He further discovered that there was a relationship between the credit risk management and profitability of selected rural banks in Ghana. The rural banks with higher capital adequacy ratio can better advance more loans and absorb credit losses whenever they crop up and therefore record better profitability.

Al-Tamimi, Miniaoui, and Elkelish (2015) examined the relationship between financial risk and performance of Gulf Cooperation Council Islamic banks and the relative importance of the most common types of risk. The study covered 11 of the 47 Islamic banks of the Gulf Cooperation Council region from 2000 to 2012. Data were obtained from the Bank scope database. ROA and ROE were used as measures for bank performance. Four types of financial risk were used, namely credit risk, liquidity risk, operational risk, and capital risk. Regression analysis indicated that there exists a significant negative relationship between the Gulf Cooperation Council Islamic banks' performance, capital risk and operational risk. The results also confirmed a significant negative relationship between Gulf Cooperation Council Islamic banks' performance and that Capital risk was the most important type of risk and then followed by operational risk.

\section{Review of Empirical Studies in Nigeria}

Aruwa and Musa (2016) examined the effects of the various risk components like credit risk, interest rate risk and operational risk on the financial performance of Deposit Money Banks in Nigeria. The study used the whole25 number of banks that were existed in Nigeria from the year 1997 to 2011 . The data were analyzed using descriptive statistics and ordinary least square regression. In the study, the researchers established that a strong relationship exists between risk components and the financial performance of the banks in Nigeria and it was indicated by the r-squared value of $91 \%$. However, variables that represent credit risk and the rate of capital to total weighted risk asset have positive relationship. Operational and interest rate risk affects the profitability of the banks negatively. This research covered a wider range of risks that are encountered in financial institutions.

Kargi (2011) evaluated the impact of credit risk on the profitability of Nigerian banks. Financial ratios as measures of bank performance and credit risk were collected from the annual reports and accounts of sampled banks from 2004-2008 and analyzed using descriptive, correlation and regression techniques. The findings revealed that credit risk management has a significant impact on the profitability of Nigerian banks. It concluded that banks' profitability is inversely influenced by the levels of loans and advances, non-performing loans and deposits thereby exposing them to great risk of illiquidity and distress.

None of these studies examined relationship between financial risks using credit risk, liquidity risk and interest rate risks as combined proxies for financial risks and as explanatory variables in determining the effect of financial risks on profitability of Deposit Money Banks in Nigeria. There are other components of financial risks like foreign exchange risk and market risk that were not captured in this study. This study is restricted to these three variables as components of financial risks. Dependent variables are Return on Asset (ROA), Return on Equity (ROE) and Earning per share (EPS) as proxies for profitability. None of the previous studies explored this dimension. These are the gaps created in other studies that this study filled.

\section{Methodology}

This study employed descriptive research design. The population of this study is made up of twenty Deposit Money Banks listed on the Nigerian Stock Exchange as at 31st December, 2017. Ten Deposit Money Making 
Banks were included in the study from the total Deposit Money Banks operating in Nigerian Banking Sector. The ten Deposit Money Banks included in the study are: First Bank of Nigeria, Guarantee Trust Bank, United Bank for Africa, Union Bank of Nigeria, Wema Bank, Access Bank, Fidelity Bank, Zenith Bank, Diamond Bank and Sterling Bank. The study covers the period of ten years (2008-2017), the post consolidation period.

The study employed secondary source of data. The source of data is from the annual financial reports of these banks. The data were presented using table, analyzed using both descriptive to determine mean and standard deviation of the variables as well as inferential statistics (correlation and regression analyses) to test the Three (3) hypotheses as well as determining the degree of relationship among the variables and the extent of change in dependent variables as a result of unit change in independent variables.

\section{Model Specification}

The model for this study established the relationship between dependent and independent.Proxies for dependent and independent variables are stated respectively; Return on Asset (ROA), Return on Equity (ROE) and Earnings per Share (EPS); Credit risk (CR), Liquidity risk (LR), Interest rate risk (IRR).

$\mathrm{ROA}_{\mathrm{it}}=\beta_{0}+\beta_{1} \mathrm{CR}_{\mathrm{it}}+\beta_{2} \mathrm{LR}_{\mathrm{it}}+\beta_{3} \mathrm{IRR}_{\mathrm{it}}+\mathrm{U}_{\mathrm{it}}$.

$\mathrm{ROE}_{\mathrm{it}}=\beta_{0}+\beta_{1} \mathrm{CR}_{\mathrm{it}}+\beta_{2} \mathrm{LR}_{\mathrm{it}}+\beta_{3} \mathrm{IRR}_{\mathrm{it}}+\mathrm{U}_{\mathrm{it}}$

$\mathrm{EPS}_{\mathrm{it}}=\beta_{0}+\beta_{1} \mathrm{CR}_{\mathrm{it}}+\beta_{2} \mathrm{LR}_{\mathrm{it}}+\beta_{3} \mathrm{IRR}_{\mathrm{it}}+\mathrm{U}_{\mathrm{it}}$

Where:

$\mathrm{ROA}=$ Return on Assets

$\mathrm{ROE}=$ Return on Equity

EPS $=$ Earnings per Share

$\mathrm{CR}=$ Credit Risk: Ratio on non-performing loan to total loan.

$\mathrm{LR}=$ Liquidity risk: Total loan and advances to total deposit liabilities.

$\mathrm{IRR}=$ Interest rate risk: ratio of maturity gap (rate sensitive assets less rate sensitive liabilities) to total capital.

$\beta_{0}=$ Constant Parameter or Intercept

$\beta_{1}=$ Coefficients of Independent Variables.

\section{A Priori Expectation}

Risks are usually defined by the adverse impact on profitability. If these risks are efficiently and effectively managed, the expected return on asset, equity and earning per share should be positive related to its risk. In line with this, the $A$ priorexpectations are: CR $>1$; LR $>1$ and IRR $>1$.

\section{Results and Discussion}

This first part of this section gives account of descriptive statistics while the second part documents the inferential statistics for the hypotheses testing and the last part of the section contained the discussion of the findings.

Table 1: Descriptive Statistics

\begin{tabular}{|c|c|c|c|c|c|c|}
\hline VAR IA B L E S & $\mathbf{O}$ & $\mathbf{R}$ & $\mathbf{S}$ & $\mathbf{R}$ & $\mathbf{R}$ & $\mathrm{C}$ \\
\hline $\mathrm{A}$ & 0.025163 & 0.013439 & 0.932551 & 0.664929 & -0.156776 & 0.085786 \\
\hline$M E$ D I A N & 0.102500 & 0.015000 & 1.035000 & 0.672000 & 0.580500 & 0.039500 \\
\hline M A X I M U M & 0.296000 & 0.276000 & 8.740000 & 1.351000 & 3.093000 & 0.840000 \\
\hline M I N I M U M & -3.944000 & -0.311000 & -21.18000 & 0.2520000 & -47.51600 & 0.01110000 \\
\hline S T D. D E V & 0.496659 & 0.058679 & 3.065199 & 0.182777 & 5.034419 & 0.137881 \\
\hline S K E W N E S S & -6.533920 & -2.201304 & -4.705542 & 0.357340 & -8.702833 & 3.764467 \\
\hline K U R T O S I S & 48.57632 & 22.14201 & 34.00879 & 3.821574 & 81.70321 & 18.06844 \\
\hline $\mathrm{O}$ B $\mathrm{S}$ E $\mathrm{R}$ V & 9 & 9 & 8 & 9 & 9 & 9 \\
\hline
\end{tabular}

Source: Researcher's Computation (2018)

\section{Correlation Matrix}

Table 2: Pearson's Correlation Coefficients For All Variables

\begin{tabular}{|c|c|c|c|c|c|c|c|}
\hline VARIABLES & $\mathbf{O}$ & $\mathbf{E}$ & $\mathbf{O}$ & $\mathbf{E}$ & $\mathbf{L}$ & $\mathbf{R}$ & $\mathbf{C}$ \\
\hline RO E & 1 & & 0.4129864 & 0.156463 & 0.238962 & 0.8492761 & -0.3829 \\
\hline ROA & 0.41298 & & 1 & 0.658112 & 0.086285 & 0.1064472 & -0.5109 \\
\hline E P S & 0.15646 & & 0.6581122 & 1 & 0.113016 & 0.0329618 & -0.3307 \\
\hline $\mathbf{L}$ & 0.23896 & & 0.0862858 & 0.113016 & 1 & 0.1829631 & -0.1059 \\
\hline I $\mathbf{R} \mathbf{R}$ & 0.84927 & & 0.1064472 & 0.032961 & 0.182963 & 1 & -0.1460 \\
\hline $\mathbf{C}$ & -0.3829 & & -0.5109596 & -0.330762 & -0.105920 & -0.1460377 & 1 \\
\hline
\end{tabular}

Source: Researcher's Computation (2018) 


\section{Analysis of Regression Results}

This presents the regression analysis result employed in the study to capture objectives one to three. The study attempts to compare the pooled regression analysis result with Random effect regression. Random effect is used because the Hausman specification test is not significant and showed that difference in the regression coefficients are not systematic and thus necessitate the adoption of Random effect regression analysis.

Table 3

3.1. Pooled Regression Result For Model I (Dependent Variable ROA)

\begin{tabular}{|c|c|c|c|c|}
\hline VAR IA B LES & COEF F I C IE N T & $\mathrm{S}$ T D & $\mathrm{T}-\mathrm{V}$ A L U E & $\mathrm{P}>$ \\
\hline CREDIT RISK & -0.214044 & 0.0377533 & -5 & $\begin{array}{ll}0 & 0\end{array}$ \\
\hline LIQUIDITY RISK & 0.00095563 & 0.0285103 & . 34 & 738 \\
\hline INT RATE RISK & 0.0000031179 & $\begin{array}{lllllllll}0 & 0 & 0 & 0 & 1 & 0 & 4 & 7 & 6 \\
\end{array}$ & 30 & 762 \\
\hline CONSTANT & 0.022535514 & 0.0200736 & 26 & 210 \\
\hline$F(3,96)$ & 4 & & & $\mathrm{PROB}>\mathrm{F}=0.0000$ \\
\hline R-SQUARED & $\begin{array}{lll}2 & 6 & 2\end{array}$ & & & \\
\hline
\end{tabular}

Source: Researcher's Computation (2018)

3.2 Autocorrelation Test for Model I

\begin{tabular}{|l|l|}
\hline Pesaran's Test of Cross Sectional Independence & 0.997 \\
\hline Probability Value & 0.3185 \\
\hline Average Absolute Value of the Off-Diagonal Elements & 0.237 \\
\hline
\end{tabular}

Average Absolute Value of the Off-Diagonal Elements

Source: Researcher's Computation (2018)

Table 4

4. 1: Pooled Regression Result for Model II (Dependent Variable ROE)

\begin{tabular}{|c|c|c|c|c|c|}
\hline VARIABLES & COEFFICIENT & STD. ERR & $T-V A$ L U E & $\mathrm{P}$ & $\mathrm{T}$ \\
\hline CREDIT RISK & -.9370733 & 0.1690592 & -5.54 & 0.00000 & \\
\hline LIQUIDITY RISK & 0.1728599 & 0.1276692 & 1.35 & 179 & \\
\hline INT RATE RISK & 0.0788859 & 0.0046911 & 16.82 & $\begin{array}{lll}0 & 0 & 0 \\
\end{array}$ & \\
\hline CONSTANT & 0.00031849 & 0.0898896 & 0.04 & 972 & \\
\hline F-STAT( 3,96$)$ & 123.14 & & & $\mathrm{PROB}>\mathrm{F}$ & 0.0000 \\
\hline R-SQUARED & 0.7937 & & & & \\
\hline
\end{tabular}

Source: Researcher's Computation (2018)

\subsection{Autocorrelation Test for Model II}

\begin{tabular}{|l|l|}
\hline Pesaran's Test of Cross Sectional Independence & 2.643 \\
\hline Probability Value & 0.0082 \\
\hline Average Absolute Value of the Off-Diagonal Elements & 0.291 \\
\hline
\end{tabular}

Source: Researcher's Computation (2018)

4.2: Pooled Regression Result for Model III (Dependent variable EPS)

\begin{tabular}{|c|c|c|c|c|c|c|c|c|}
\hline VAR & COEF & STD. ERR & T-VALUE & P $>|\mathbf{T}|$ & COEF. & STD. ERR. & Z-VAL & P $>|Z|$ \\
\hline C.R & 7.263202 & 2.158761 & -3.36 & 0.001 & -6.541936 & 2.414336 & $-1.00-$ & 0.342 \\
\hline L.K & 1.39377 & 1.63024 & 0.85 & 0.395 & -0.7086638 & 2.028329 & -0.35 & 0.728 \\
\hline I.R.R & -0.0182563 & 0.059902 & -0.30 & 0.761 & 0.0016105 & 0.0144663 & 0.039 & 0.980 \\
\hline CONST & 0.626264 & 1.147823 & 0.55 & 0.587 & 1.961384 & 0.8597486 & 2.28 & 0.0163 \\
\hline F (3,96) & 4.22 & & & $\begin{array}{c}\text { PROB } \\
\text { F } \\
=0.0075\end{array}$ & 72.37 & & & $\begin{array}{c}\text { PROB }>\text { CHI2 }= \\
0.0000\end{array}$ \\
\hline $\begin{array}{c}\text { HAUSMAN } \\
\text { (ch12(1) }\end{array}$ & & & & 12.96 & & & $\begin{array}{c}\text { PROB }>\text { CHI2 } \\
= \\
0.0013\end{array}$ \\
\hline R $^{2}$ & 0.1166 & & & & 0.1000 & & & \\
\hline
\end{tabular}

Source: Researcher's Computation (2018)

\subsection{Autocorrelation Test for Model III}

\begin{tabular}{|l|l|}
\hline Pesaran's Test of Cross Sectional Independence & 3.045 \\
\hline Probability Value & 0.0023 \\
\hline Average Absolute Value of the Off-Diagonal Elements & 0.360 \\
\hline
\end{tabular}

\section{Source: Researcher's Computation (2018)}

\section{Discussion of Findings}

The Relationship Between Return on Assets (ROA) and Financial Risks (MODEL 1)

The Random effect regression result showed that credit risk (CR) has a significant negative relationship with return on asset (ROA). A unit increase in CR will result to -0.214044 decrease in ROA which simply implies that the 
more exposed the deposit money bank in Nigeria is to Credit risk, the lower the return on their Assets. The implication here is that the percentage of non-performing is high in deposit money banks in Nigeria. It is important to note that the study assumed the same managerial and administrative competencies for all the banks under survey. The further implication of this relationship between ROA and CR is that CR can be said to be a major factor affecting ROA in most deposit money banks in Nigeria. It is therefore, imperative for deposit money banks to identify this factors and manage them in a way that increase the profitability of deposit money banks through increasing ROA. However, there was a positive and insignificant relationship $0.0095563(\mathrm{p}=0.738)$, between ROA and liquidity risk. Also, there was insignificant positive relationship of 0.0003179 ( $\mathrm{p}=0.762)$ between ROA and interest rate risk. R-square of $26 \%$ variation in ROA is explained by credit risk, liquidity risk and interest rate risk while the remaining $74 \%$ is explained by other factors affecting ROA not included in the model. Therefore, the result necessitates the rejection of the first null hypothesis of no significant relationship between credit risk and return on asset(ROA) and failure to reject the alternative hypothesis of significant relationship between liquidity risk and return on asset. This result is significant at 5\% level of significance. The negative significant relationship between credit risk and profitability as confirmed that this study is in agreement with Akhtar, Ali and Sadaqat (2011), Kolapo, (2012) in Nigeria, Lake (2013), Amin (2014) in Tanzania.

\section{The Relationship between Return on Equity (ROE) and Financial Risks (MODEL I1)}

Random effect regression result of the study for model II showed that credit risk and interest rate risk have a significant negative and positive relationship with return on equity respectively. A unit increase in CR and INTR will result to -0.9370733 and 0.0788859 change in ROE respectively. Liquidity Risk has an insignificant positive relationship with return on equity. This result is significant at $5 \%$ level of significance. The Hausman result showed that we can reject the null hypothesis of preferable fixed effect model and fail to reject the alternative hypothesis of preferable random effect model because the probability value is insignificant and confirmed that difference in coefficient is not systematic. Again, the Wald (CHI) result and its respective probability figure showed that the model is good. This shows that the co-efficient in the model are not difference than zero. In the same vein, approximately $79 \%$ variation in ROE is explained by the included explanatory variables while the remaining $21 \%$ is explained by other factors affecting ROE not included in the model. One important thing to note here is that the result of the Random effect model is similar to that of pooled regression analysis result. Also, liquidity risk does not influence ROE which could be as a result of poor policy by management of deposit-money banks to adopt policies to drive ROE through LR. This could also be the natural outcome of unfavorable environment for business in the country due to government failures. The positive effect liquidity risk on profitability is in line with the study of Bordeleau (2010) in USA, Shen, Cheukao and Yek (2009) and Ibe (2013) in Nigeria.

\section{The Relationship between Earning Per Share (EPS) and Financial Risks (MODEL II1)}

The result showed credit risk has negative and significant relationship with Earning per Share. This result is significant at 5\% level of significance. There is positive and insignificant relationship between EPS and interest rate. This shows that the co-efficient in the model are difference than zero. In the same vein, approximately $10 \%$ variation in EPS is explained by included explanatory variables while the remaining $90 \%$ is explained by other factors affecting EPS not included in the model.The F-stat result and its respective probability figure showed that the model is good. The outcome of this result is in agreement with Eneyew (2013) in Ethiopia.

\section{Conclusion}

The study concluded that credit risk has significant negative effect and inverse relationship with the return on assets (ROA) of Deposit Money Banks in Nigeria. This is due to the higher non-performing loans that may arise as a result of the improper credit management system. Also, it concluded that liquidity risk has positive but insignificant effect on return on equity. It implies that Nigerian banks are liquid. There is no liquidity problem in the system as they all complied with the minimum liquidity ratio of $30 \%$ as prescribed by the CBN. However, there is potential for liquidity risk if banks fail in their duty to effectively and efficiently manage their liquidity. It is concluded from the study that Interest rate risk has positive and insignificant relationship with earning per share. The implication is that interest rate risk is not a major determinant of Earning per Share, rather deposit money banks should focus on other factors that promote earning per share in order to increase their profitability level.

\section{Recommendations}

In line with the findings of the study, the results obtained from the regression analysisrevealed that, among all the risks that deposit money banks in Nigeria faced, credit risk was the major factor that can adversely affect their profitability. Therefore;

i. Deposit Money Banks in Nigeria should focus on credit risk management on the bases ofmaximizing return on its assets while keeping its credit exposure within acceptable limits.

ii. To do so the bank should regularly review their credit portfolio quality, provisioning requirements, and 
customer exposure.

iii. Higher non-performing loans may arise as a result of the improper credit management system of the deposit money banks in Nigeria or as a problem of financial system of the country. Therefore, there should be an improvement in these system such as checking their credit policies and practices.

\section{References}

Afriyie, (2011). Credit Risk Management and Profitability of Selected Rural Banks in Ghana Catholic University College of Ghana. 1-18.

Akhtar, M., Ali, K., \& Sadaqat, S. (2011). Liquidity Risk Management: A comparative study between Conventional and Islamic Banks of Pakistan. Interdisciplinary Journal of Research in Business, 1(1), 35-44.

Amin, (2014). The Electronic Journal of Information Systems in Developing Countries - Wiley Online Library https://onlinelibrary.wiley.com $>$ doi $>$ abs

Al-Tamimi, Minioaui \& Elkelish (2015). Financial Risk and Islamic Banks Performance in the GCC Countries Research, 9(5) 103-112.

Aruwa \& Musa 2016. Risk Components and the Financial Performance of Deposit Money Banks in Nigeria. International Journal of Social Sciences and Entrepreneurship (11).

Baldwin, C. Y. \& Scott, P. M. (1983). The Resolution of claims in financial distress the case of Messey Ferguson. The Journal of Finance 38(2) 505-510/

Basel Committee on Banking Supervision, (2007). Sound Practices for managing Liquidity in Banking Organisations. Bank for International Settlements.

Bessis, 2005. Risk Management in Banking 2 ${ }^{\text {nd }}$ Edition: Amazon.co.uk: Joel Bessis: 9780471893363: Books hppts://www.amazon.co.uk > Risk - Management.

Bordeleau, E and Grahan, C. (2010), The Impact of Liquidity on Bank Profitability. Bank of Canada Working Paper 2010-38

Claudiu, H and Daniela, N (2009), Performance Evaluation Methods in Commercial Banks.

Collier, P. (2009), Fundamentals of risk management for accountants and managers ( $1^{\text {St }}$ d). Elsevier Ltd., Oxford, UK.

Crouhy, M.; Galai, D. \&Mark,. (2006). The Essentials of Risk Management. McGraw-Hill. USA.

Drigă I., 2007. Risks Analysis and Management in Banking, University as Publishing House.

Duffie, D. \& Singleton, K. (2003). An econometric model of the structure of interstate swap yields.

Elsinger, H., Lehar A., \& Summer, M (2003). Risk Assessment for Banking Systems, $14^{\text {th }}$ Annual Utah Winter Finance Conference (437), USA

Eneyew, L. (2013). Financial Risks and Profitability of Commercial Banks in Ethiopia. Unpublished Master's Thesis. Addis Ababa University, Ethiopia, Addis Ababa, Ethiopia.

Gande, A. (2008). Internet Rate Risk Management with Debt Issue: Evidence from Europe Journal of Financial Stability 36: 1-11

Grenning \& Bratanovic, 2009. Analyzing and Managing Bank Risk: a Framework for assessing Corporate Governance and Financial Risk Management (English) The World Bank Documents. Worldbank.org $>$ curated $>$ A

Holton, G. (2004). Defining Risk. Financial Analysts Journal, 60(6), 19-25.

Ibe S.O. The impact of liquidity management on the profitability of banks in Nigeria. Journal of Finance \& Bank Management. 2013;1(1).Intermediate Technology Publication Ltd., London.Issue 66, (Jhingan, 2010) International Economics (Sixth Edition) :Vrnda Publication (P) Ltd.

Kargi, H.S. (2011). Credit Risk and the performance of Nigerian Banks. Ahmadu Bello University,Zaria.

Kolapo, T.F., Ayeni, R.K., \& Oke M.J. (2012). Credit risk and Commercial Banks Performance in Nigeria: A Panel Model Approach Australian Journal of Business and Management Research. 2(2) (31-38).

Lartey \& Boadi 2013. The Relationship between Liquidity and Profitability of Listed Banks In Ghana International Journal of Business and Social Science 4(3)

Lake (2013) Financial Risk and Profitability of Commercial Banks in Ethiopia (Unpublished Doctoral dissertation, Addis Ababa University, Addis Ababa, Ethiopia).

Meyer, L 2000 'Why Risk Management Is Important for Global Financial Institutions’ BIS Review 68/2000

NBE 2010. National Bank of Ethiopia 2010/11 Annual Report VII. Investment 16.

NDIC (2006). Annual Report and Account of Banks Submit.

Ngwu, T.C. (2006). Bank Management. Owerri: Bob Publishers.Nigeria. Journal of Finance \& Bank Management. 1(1). Nigeria: A panel Model Approach. Australian Journal of Business and Management of commercial banks in Kenyaee, Economics and Finance Review, Vol. 1, no. 5, of finance, National Taiwan University and National University of Kaohsiung.

Oluwasanmi, O., Uwuigbe U., \& Uwuigbe O. R (2015). The effect of risk Management on Bank's financial performance in Nigeria. Journal of Accounting \& Auditing: Research \& Practice, 20(15), 62-66. 
Owojori, A. A., Akintoye, R. I., \& Adidu, A. F. (2011). The challenge of risk management in Nigeria banks in the post consligation era. Journal of Accounting and Taxation. 13(2). 23-31.

Rose, P (2008). Commercial Bank Management. (5thedn) Mc Graw-Hill/Irwin, USA

Shen, C., Chen, Y., Kao, L. \& Yeh, C. (2009). Bank liquidity risk and performance. Department of Finance, National Taiwan University and National University of Kaohsiung.

Soludo, C. 2004). 'Consolidating the Nigerian Banking Industry Industry to Meet the Development of the $21 \mathrm{st}$ Century'. Being an address delivered to the Special Meeting of the Bankers' Committee, held on July 6, 2004 at the CBN Headquarter, Abuja.

Tafri, H, Hamid, Z, Meera, M and Omar, A (2009), The Impact of Financial Risks on Profitability of Malaysian Commercial Banks: 1996-2005"e, International Journal of Social and Human Sciences 31 (672-1686).

Vento and Ganga (2009). Bank Liquidity Risk Management and Supervision: Which Lessons from Recent Market Turmoil? Journal of Money, Investment and Banking. Euro Journal Publishing.

Whitaker (1999), The early stage of financial distress. Journal of Economics and Finance 23(2), 123-132. 